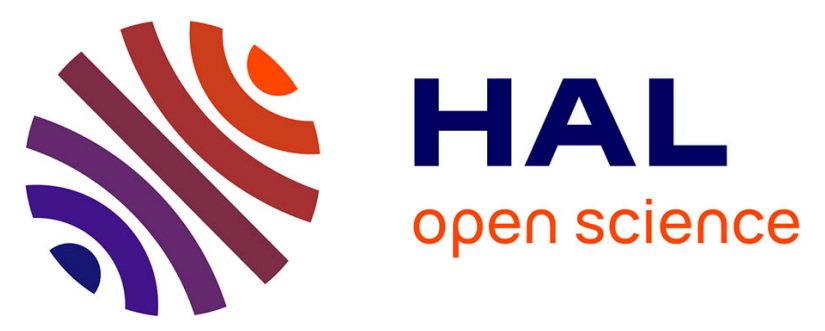

\title{
Patterns of genetic variation do not correlate with geographical distance in the reef-building coral Pocillopora meandrina in the South Pacific.
}

Hélène Magalon, M. Adjeroud, M. Veuille

\section{- To cite this version:}

Hélène Magalon, M. Adjeroud, M. Veuille. Patterns of genetic variation do not correlate with geographical distance in the reef-building coral Pocillopora meandrina in the South Pacific.. Molecular Ecology, 2005, 14 (7), pp.1861-8. 10.1111/j.1365-294X.2005.02430.x . hal-00941691

\author{
HAL Id: hal-00941691 \\ https://hal.science/hal-00941691
}

Submitted on 6 May 2016

HAL is a multi-disciplinary open access archive for the deposit and dissemination of scientific research documents, whether they are published or not. The documents may come from teaching and research institutions in France or abroad, or from public or private research centers.
L'archive ouverte pluridisciplinaire HAL, est destinée au dépôt et à la diffusion de documents scientifiques de niveau recherche, publiés ou non, émanant des établissements d'enseignement et de recherche français ou étrangers, des laboratoires publics ou privés. 


\title{
Patterns of genetic variation do not correlate with geographical distance in the reef-building coral Pocillopora meandrina in the South Pacific
}

\author{
H. MAGALON,${ }^{*}$ M. ADJEROUD十‡ and M. VEUILLE* \\ *Ecole Pratique des Hautes Etudes/UMR CNRS 7625, Laboratoire d'Ecologie, Université Pierre et Marie Curie, 7 Quai Saint Bernard, \\ 75005 Paris, France, +Ecole Pratique des Hautes Etudes, Laboratoire de Biologie Marine et Malacologie, UMR CNRS 8046, Université \\ de Perpignan, 66860 Perpignan, France
}

\begin{abstract}
Dispersal may be a critical factor in the ability of reef-building corals to recover after major disturbances. We studied patterns of geographical structure using four microsatellite markers in seven South Pacific populations of Pocillopora meandrina, a major coral species from Polynesia. Variation within populations showed evidence of heterozygote deficiency. Genetic differentiation between populations was detected at a large scale $(2000 \mathrm{~km})$ between the Tonga and the Society Islands. Within the Society Islands, four of the five studied populations from Bora Bora, Moorea and Tahiti were not significantly different from each other. Unexpectedly, one of the three populations surveyed in Moorea was genetically different from the other two populations of this island (that were 5 and $10 \mathrm{~km}$ apart), and from the populations of the other two surveyed islands in this archipelago. We cannot rule out the possibility that this pattern is an equilibrium state, whereby short-range dispersal is locally more differentiating than long-range dispersal, as has been suggested by similar patterns reported in other studies. An alternative explanation that is globally consistent with all observations is that this is the signature of a large-scale destruction event, as for instance a bleaching event, followed by the recent restoration of populations by new colonists.
\end{abstract}

\section{Introduction}

Disturbance, including large-scale bleaching events, has dramatically increased recently in coral reef ecosystems (Richmond 1993; Nyström et al. 2000). The resilience of these destructed biota largely depends on the ability of corals to recover and to colonize disturbed areas. In this study, we use genetic markers to investigate gene flow in Pocillopora meandrina, a major reef-building coral of the Society Islands (French Polynesia, south-central Pacific).

Correspondence: Michel Veuille, Department Systematique et Evolution Museum National d'Historie Naturelle, 16 rue Buffon 75005 Paris; Fax: (†33)1 407933 27; E-mail: veuille@mnhn.fr. $\ddagger$ Present address: CRIOBE (Centre de Recherches Insulaires et Observatoire de l'Environnement), BP 1013 Papetoai, Moorea, French Polynesia.
The pelagic larvae of marine invertebrates sometimes disperse over very long ranges. Dispersal distances of thousands of kilometres have been reported in scleractinian corals (Jokiel 1984). High dispersal may result in mild and uniform genetic differentiation between islands spread over a large scale (Palumbi 1992). However, a planktonic phase does not always result in uniform dispersal among subpopulations (Parsons 1996). Gene flow depends on a number of parameters, including the biological ability to disperse, the habitat, the oceanic conditions and the past geographical isolation between populations. These factors may create genetic divergence that cannot be directly comprehended by standard models (Palumbi 1994).

Corals show a variety of reproductive systems that may directly influence their potential for dispersal. They are either hermaphrodite or gonochoric, and brooders or broadcasters (review in Carlon 1999). Broadcasters are 


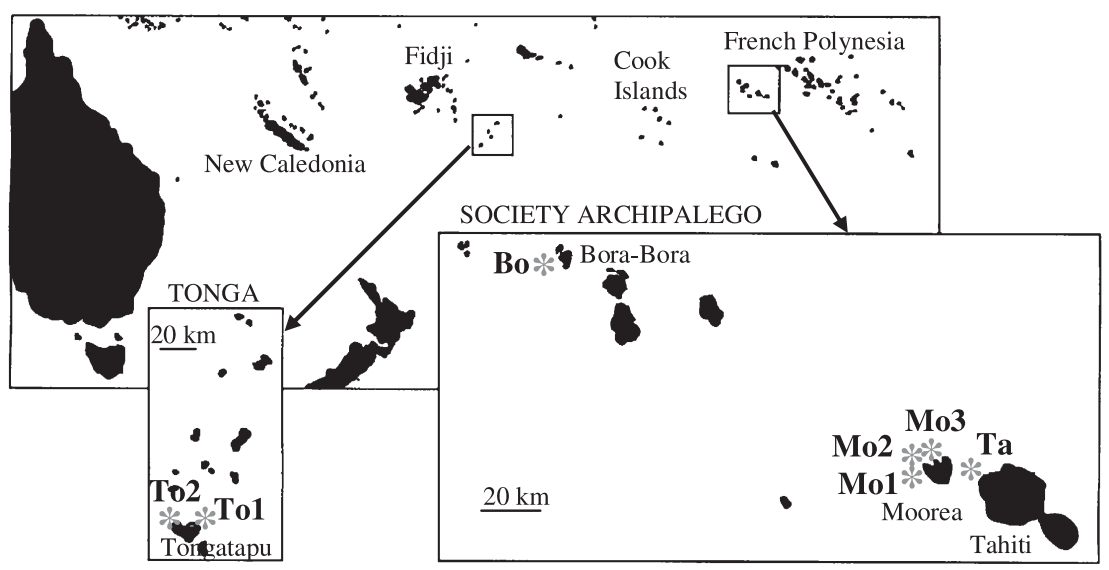

Fig. 1 Geographic origin of Pocillopora meandrina; population names are in bold.

thought to be great dispersers (Willis et al. 1997), whereas brooders are considered to be poor dispersers with the potential for self-fertilization (Carlon 1999). These two modes can coexist in the same species and may vary across the species range (Ward 1992; Shlesinger et al. 1998). The breeding system of a coral can thus play an important role in the structuring of populations (Nishikawa et al. 2003). Asexual reproduction also exists in some corals in a variety of forms, including fragmentation (Highsmith 1982), budding or polyp expulsion (Kramarsky-Winter et al. 1997) and asexually produced planulae (Stoddart 1983; Ayre \& Resing 1986).

This study focuses on P. meandrina, a dominant reefbuilding coral from the French Polynesia. Pocillopora is a widespread genus in the Indo-Pacific, especially in the central and far eastern Pacific. Sympatric species are sometimes difficult to identify (Veron 2000) and there is circumstantial evidence suggesting hybridization with the related species Pocillopora verrucosa. P. meandrina is a shallow water-branching coral found both in outer slopes and in lagoons. It is a broadcaster in the French Polynesia (Adjeroud, unpublished), but little is known about its spawning behaviour (seasonal timing, possibility of mass spawning). This is the first genetic study carried out on this species, whereas a number of studies have looked at $P$. verrucosa and Pocillopora damicornis, two related reef-buildings corals in the Pacific (Stoddart 1984a, 1984b; Benzie et al. 1995; Ayre et al. 1997; Adjeroud \& Tsuchiya 1999; Ayre \& Hughes 2000; Ridgway et al. 2001; Miller D. J. \& Ayre 2004).

Until recently, most population genetics studies on Scleractinia were carried out using allozymes. Microsatellites were thought to be rare in corals, as for instance in Acropora (Marquez et al. 2003). The difficulty in isolating coral DNA markers is increased by the presence of intracellular symbiotic zooxanthellae. However, microsatellites have recently been successfully isolated from scleractinian corals (Maier et al. 2001; Le Goff \& Rogers 2002; Magalon et al. 2004; Miller \& Howard 2004; Severance \& Karl 2004) and used in population genetics studies (Lopez et al. 1999;
Le Goff-Vitry et al. 2004; MacKenzie et al. 2004a). Using these markers, the main focus of this study is to investigate the geographical differentiation of this species in the Society Islands, across a range of about $200 \mathrm{~km}$. However, we also sampled populations at two different scales: (i) we sampled populations from Tonga (2000 km away), to determine if large scale genetic differentiation occurs within the species range if no small scale structure exists, and (ii) at a local scale, we studied genetic relationships among neighbouring corals, to control for a possible bias as a result of reef fragmentation.

\section{Materials and methods}

\section{Sample collections}

Samples were collected from four islands as shown on Fig. 1. Three islands (east to west: Tahiti, Moorea and Bora Bora) belong to the Society Islands. The fourth (westward) is Tongatapu in the Tonga Archipelago. From Tahiti, the distances to the other islands are $20 \mathrm{~km}$ (Moorea), $200 \mathrm{~km}$ (Bora Bora) and $2000 \mathrm{~km}$ (Tonga). The Tahiti population (hereafter Ta) was sampled in December 2003. Three populations were sampled from Moorea, at $5 \mathrm{~km}$ intervals, in March 2001: Haapiti (hereafter Mo1), Tiahura (Mo2), and Vaipahu (Mo3). The Bora Bora population (Bo) was sampled in December 2003. Two populations from Tonga were sampled in August 2002 (To1 and To2). All samples were collected from the outer reef slope, except To1, which was collected from the lagoon.

Branch tips were collected along a linear transect at $13 \mathrm{~m}$ depth on all sites, except To1 (2-6 m depth). Colonies were sampled every $5 \mathrm{~m}$ along the transect. In order to detect possible cases of asexual propagation, tips from the closest neighbour of each colony were collected for Mo1, Mo2 and Mo3. All individuals were identified as Pocillopora meandrina using morphoanatomical criteria. Samples were preserved in $70 \%$ ethanol until use. Total DNA was extracted using the DNEasy Tissue Kit (QIAGEN), following the 
manufacturer's instructions, from $300 \mathrm{mg}$ of coral powder obtained by grinding branch tips.

\section{Microsatellite typing}

We used four coral-specific microsatellites (PV2, PV5, PV6, PV7) formerly developed for Pocillopora verrucosa and found to be polymorphic in P. meandrina (Magalon et al. 2004). Amplification and genotyping were performed as formerly described (Magalon et al. 2004).

\section{Data analyses}

The average number of alleles per locus within populations $\left(n_{a}\right)$, observed and expected heterozygosity $\left(H_{\mathrm{O}}\right.$ and $\left.H_{\mathrm{E}}\right)$ and the inbreeding coefficient $\left(F_{\text {IS }}\right)$, were calculated for each locus and for each sample. Tests of departure from Hardy-Weinberg equilibrium (HWE) were performed using exact probability tests based on a Markov chain approach (Guo \& Thompson 1992). Pairwise linkage disequilibrium between loci in each population was used to assess independence between loci. These analyses were carried out using GENEPOP version 1.2 (Raymond \& Rousset 1995) and GENECLASs 2 version 2.0 (Piry et al. 2003). Sequential Bonferroni corrections were used whenever applicable (Rice 1989).

The significance of genetic differentiation between populations was examined using an exact test with GENEPOP version 1.2. The joint probability over all loci was obtained using Fisher's combined probability tests (Sokal \& Rolf 1995). The pairwise $F_{\mathrm{ST}}$ statistic between populations was calculated after Weir \& Cockerham (1984) using ARLEQUIN version 2.00 (Schneider et al. 2000). A hierarchical estimation of $F$ statistics with a two-level AMovA was performed using ARLEQUIN version 2.00. Nei's unbiased genetic distance $(D)$ (Nei 1978) was calculated between pairs of populations (for each locus separately, and over all loci) using SPAGEDI version 1.1 (Hardy \& Vekemans 2002). Genetic distances were graphically represented using the neighbourjoining option of MEGA version 2.1 (Kumar et al. 2001).

The significance of Pearson's correlation coefficient between genetic distance, using Slatkin (1993) linear correction $F_{\mathrm{ST}} /\left(1-F_{\mathrm{ST}}\right)$, and geographical distance (estimated as the logarithm of distance, Rousset 1997) was assessed using a Mantel test based on the distribution of 1000 randomized matrices using GENEPOP version 1.2.

Asexual propagation was checked by comparing the total number of multilocus genotypes $\left(N_{i}\right)$ and the number of unique multilocus genotypes $\left(N_{g}\right)$ per population. In each population from Moorea, we compared the relatedness between neighbouring individuals to the relatedness for all other possible pairs of individuals. We used the Queller \& Goodnight (1989) estimator as calculated by SPAGEDI version 1.1 .

\section{Results}

\section{Genetic variation}

Results are shown in Table 1. Among 42 linkage disequilibrium tests, only three were significant at the $5 \%$ level and none were significant after Bonferroni correction. All loci can therefore be considered genetically independent. The number of alleles per locus varied from four (PV7) to 18 (PV5) over all populations. Genetic diversity $\left(H_{\mathrm{E}}\right)$ was comparatively high in the two samples from Tonga (0.804 and 0.822) and a sample from Moorea (Mo1: 0.828), and low in the other four Society Island samples (0.675-0.722).

\section{Inbreeding and relatedness}

There was no evidence that any two individuals from our sampling had originated through asexual reproduction, as the number of unique multilocus genotypes $N_{g}$ was equal to the number of multilocus genotypes $N_{i}$. That is, all genotypes/individuals were different (Table 1). The coefficient of relatedness $(r)$ was calculated separately for paired and for unpaired individuals in each of the three populations from Moorea (Mo1, Mo2 and Mo3). The two distributions showed equal variances and means; the geographical distance between any two individuals was never correlated with their genetic relatedness coefficient $\left(r^{2}<10^{-3}\right)$. These results show that sexual reproduction is not restricted to short distances. Despite these observations, an excess of homozygotes was observed in all populations. The proportion of heterozygotes across loci ranged from 0.56 in Bo to 0.77 in To1. Of 28 Hardy-Weinberg tests, 12 instances of heterozygote deficiencies, involving all seven populations, were significant at $5 \%$ level after Bonferroni correction.

\section{Population differentiation}

Exact tests of genetic differentiation were computed for all pairs of populations. The Tonga populations were significantly differentiated from the Society populations. Within the Society archipelago, population Mo1 from Moorea was significantly different from all other populations (including the other two Moorea populations, Tahiti and Bora Bora). The significant pairwise $F_{\mathrm{ST}}$ between populations (Table 2) ranged from 0.02 (Mo1 vs. Ta) to 0.16 (Bo vs. To1). The same analyses, excluding one locus each time, gave the same results as the overall test. Results from an Amova (Table 3) confirmed this by showing that only a moderate amount of variation (10.49\%) was involved in differentiation between archipelagos. The percentage of variation among populations within archipelagos was very low $(0.94 \%)$. A neighbour-joining tree using Nei's unbiased distances (Fig. 2) illustrates these results: the 


\begin{tabular}{|c|c|c|c|c|c|c|}
\hline Populatio & $\mathrm{N}$ & $N_{i}^{\dagger}$ & $n_{a} \pm \mathrm{SD}$ & $H_{\mathrm{O}} \pm \mathrm{SD}$ & $H_{\mathrm{E}} \pm \mathrm{SD}$ & $F_{\text {IS }}$ \\
\hline \multirow{2}{*}{\multicolumn{7}{|c|}{$\begin{array}{l}\text { Society Archipelago, French Polynesia: } \\
\text { Moorea Island: } \\
\text { pop Mo1 }\end{array}$}} \\
\hline & & & & & & \\
\hline PV7 & 46 & & 9 & 0.733 & 0.783 & 0.064 \\
\hline PV2 & 47 & & 13 & 0.362 & 0.721 & $0.501^{*}$ \\
\hline PV5 & 43 & & 18 & 0.674 & 0.912 & $0.262^{*}$ \\
\hline \multirow[t]{2}{*}{ PV6 } & 45 & & 17 & 0.800 & 0.898 & 0.038 \\
\hline & 47 & 40 & $14.75 \pm 4.11$ & $0.642 \pm 0.194$ & $0.828 \pm 0.092$ & $+0.226^{*}$ \\
\hline \multicolumn{7}{|c|}{ pop $\mathrm{Mo2}^{*}$} \\
\hline PV7 & 50 & & 5 & 0.380 & 0.572 & 0.338 \\
\hline PV2 & 50 & & 7 & 0.520 & 0.566 & 0.083 \\
\hline PV5 & 48 & & 17 & 0.625 & 0.870 & $0.284^{*}$ \\
\hline \multirow[t]{2}{*}{ PV6 } & 50 & & 14 & 0.800 & 0.881 & 0.084 \\
\hline & 50 & 48 & $10.75 \pm 5.68$ & $0.581 \pm 0.177$ & $0.722 \pm 0.177$ & $0.197^{*}$ \\
\hline \multicolumn{7}{|c|}{ pop Мo3 } \\
\hline PV7 & 50 & & 6 & 0.400 & 0.597 & $0.332^{*}$ \\
\hline PV2 & 50 & & 10 & 0.360 & 0.531 & $0.324^{*}$ \\
\hline PV5 & 50 & & 13 & 0.714 & 0.863 & $0.174^{*}$ \\
\hline \multirow[t]{2}{*}{ PV6 } & 50 & & 15 & 0.920 & 0.876 & 0.020 \\
\hline & 50 & 49 & $11 \pm 3.92$ & $0.599 \pm 0.266$ & $0.717 \pm 0.179$ & $0.212^{*}$ \\
\hline \multicolumn{7}{|c|}{$\begin{array}{l}\text { Tahiti Island: } \\
\text { pop Ta }\end{array}$} \\
\hline PV7 & 30 & & 4 & 0.633 & 0.590 & -0.075 \\
\hline PV2 & 30 & & 8 & 0.367 & 0.561 & $0.350^{*}$ \\
\hline PV5 & 30 & & 7 & 0.700 & 0.835 & 0.164 \\
\hline \multirow[t]{2}{*}{ PV6 } & 30 & & 13 & 0.900 & 0.889 & 0.019 \\
\hline & 30 & 30 & $8 \pm 3.74$ & $0.650 \pm 0.22$ & $0.719 \pm 0.167$ & 0.097 \\
\hline \multicolumn{7}{|c|}{$\begin{array}{l}\text { Bora Bora Island: } \\
\text { pop Bo }\end{array}$} \\
\hline PV7 & 30 & & 5 & 0.467 & 0.563 & 0.174 \\
\hline PV2 & 30 & & 6 & 0.267 & 0.438 & $0.396^{*}$ \\
\hline PV5 & 30 & & 9 & 0.875 & 0.834 & 0.188 \\
\hline \multirow{2}{*}{ PV6 } & 30 & & 12 & 1 & 0.924 & 0.028 \\
\hline & 30 & 30 & $8 \pm 3.16$ & $0.558 \pm 0.246$ & $0.675 \pm 0.208$ & $0.175^{*}$ \\
\hline \multicolumn{7}{|c|}{ Tonga Archipelago: } \\
\hline \multicolumn{7}{|c|}{$\begin{array}{l}\text { Tongatapu Island: } \\
\text { pop To1 (Lagoon) }\end{array}$} \\
\hline PV7 & 25 & & 6 & 0.500 & 0.739 & $0.086^{*}$ \\
\hline PV2 & 23 & & 7 & 0.458 & 0.748 & $0.362^{*}$ \\
\hline PV5 & 24 & & 9 & 0.739 & 0.820 & -0.050 \\
\hline \multirow[t]{2}{*}{ PV6 } & 25 & & 15 & 0.880 & 0.906 & -0.052 \\
\hline & 25 & 22 & $9.25 \pm 4.03$ & $0.768 \pm 0.225$ & $0.822 \pm 0.077$ & $0.067^{*}$ \\
\hline \multicolumn{7}{|c|}{ pop To2 (Outer Slope) } \\
\hline PV7 & 24 & & 7 & 0.548 & 0.661 & 0.328 \\
\hline PV2 & 24 & & 10 & 0.402 & 0.616 & $0.393^{*}$ \\
\hline PV5 & 23 & & 8 & 0.714 & 0.850 & 0.101 \\
\hline \multirow{2}{*}{ PV6 } & 25 & & 15 & 0.876 & 0.893 & 0.014 \\
\hline & 25 & 22 & $10 \pm 3.56$ & $0.644 \pm 0.2$ & $0.804 \pm 0.077$ & $0.202^{*}$ \\
\hline
\end{tabular}

Table 1 Variation in each population for the four loci. Average values are in bold. $N$, population size; $N_{i}$, number of four-locus genotypes; $n_{a^{\prime}}$ number of alleles; $H_{\mathrm{O}}$, observed heterozygosity; $H_{\mathrm{E}^{\prime}}$ expected heterozygosity; $F_{\text {IS }}$ inbreeding coefficient

*Significant at $P<0.05$ for Hardy-Weinberg departure, using a sequential Bonferroni correction; $+N_{g^{\prime}}$ the number of unique four-locus genotypes was always equal to $N_{i}$.

\begin{tabular}{|c|c|c|c|c|c|c|c|c|}
\hline & & Mo1 & Mo2 & Mo3 & $\mathrm{Ta}$ & Bo & To1 & To2 \\
\hline Society & Mo1 & - & & & & & & \\
\hline \multirow[t]{4}{*}{ Archipelago } & Mo2 & $0.021+$ & - & & & & & \\
\hline & Mo3 & $0.022+$ & -0.005 & - & & & & \\
\hline & $\mathrm{Ta}$ & $0.019^{*}$ & -0.008 & -0.004 & - & & & \\
\hline & Bo & $0.033+$ & -0.006 & -0.006 & -0.006 & - & & \\
\hline \multirow[t]{2}{*}{ Tonga } & To1 & $0.070+$ & $0.129+$ & $0.141 \dagger$ & $0.120+$ & $0.157+$ & - & \\
\hline & To2 & $0.062+$ & $0.099+$ & $0.111 \dagger$ & $0.096+$ & $0.130+$ & 0.007 & - \\
\hline
\end{tabular}

Table 2 Pairwise multilocus estimates of $F_{\mathrm{ST}}$.

${ }^{*} P=0.01 ;+P=0.001$ probability level. 


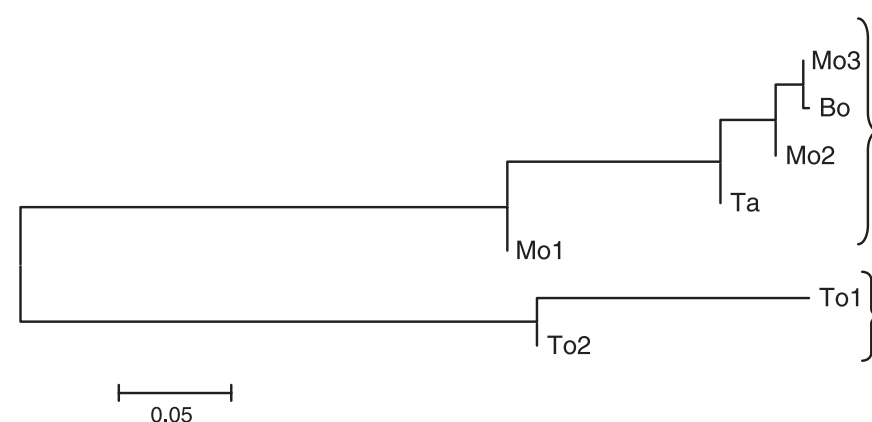

Table 3 Partition of genetic variation in Pocillopora meandrina using AMOVA

\begin{tabular}{|c|c|c|c|c|}
\hline Source of variation & DF & $\begin{array}{l}\text { Variance } \\
\text { components }\end{array}$ & $\begin{array}{l}\text { Percentage } \\
\text { of variation }\end{array}$ & $P$-value \\
\hline Among archipelagos & 1 & 0.171 & 10.49 & 0.039 \\
\hline Among populations & 5 & 0.015 & 0.94 & $<0.000$ \\
\hline $\begin{array}{l}\text { Within archipelagos } \\
\text { Within populations } \\
\text { Total }\end{array}$ & $\begin{array}{l}507 \\
513\end{array}$ & $\begin{array}{l}1.447 \\
1.634\end{array}$ & 88.57 & $<0.000$ \\
\hline
\end{tabular}

Tonga populations were very different from the others, whereas in Society Islands, Mo1 was differentiated from the other four populations, including those from the same island. A Mantel test including all populations detected a significant correlation between geographical and genetic distance estimated through $F_{\mathrm{ST}}\left(P=0.012, r^{2}=0.83\right)$. The same test including only the populations from the Society Archipelago detected no significant correlation $(P=0.65)$.

\section{Discussion}

The object of this study was to study gene flow in Pocillopora meandrina in the Society Islands. Two distant populations from Tonga were included to show that gene flow is restricted at a larger scale. Likewise, some analyses were carried out at a small scale in order to exclude asexual propagation (through fragmentation) and limitations to the dispersal of planulae as alternative explanations for observations. It was not, however, within the scope of this study to give an exhaustive account of either gene flow across the Pacific Ocean, or panmixis at a microgeographical scale.

The two main results of this study are (i) that all populations exhibit some deficit in heterozygotes and (ii) that the pattern of genetic differentiation does not match the geographical pattern of population sampling in the Society Islands.

\section{Heterozygote deficiency}

All populations exhibited some deficit of heterozygotes (significant $F_{\mathrm{IS}}$ ranged from 0.09 to 0.50 ). This has been
Fig. 2 Neighbour-joining tree of all the populations using Nei's unbiased distances $D$.

French Polynesia

Tonga

previously observed in other coral species and in other locations (Ayre \& Dufty 1994; Ayre et al. 1997; Ayre \& Hughes 2000; Ridgway et al. 2001; Whitaker 2004). A deficit in heterozygotes is frequently observed in marine invertebrates, including molluscs (e.g. Gaffney et al. 1990; David et al. 1995; Bierne et al. 1998). A deficit in heterozygotes can be mimicked by null alleles (Pemberton et al. 1995). This was checked by assuming that some of the observed homozygotes were actually heterozygous for the null allele, and that individuals failing to amplify were homozygous for the null allele. This explanation was not supported, as there was no significant increase in the frequency of individuals failing to amplify for the loci showing the highest proportions of heterozygote deficiency (results not shown).

Three population mechanisms can result in a deficiency of heterozygotes. First, the level of inbreeding can be increased by self-fertilization or by the restricted dispersal of gametes. In marine sessile invertebrates that are spawning broadcasters, like $P$. meandrina, self-fertilization can guarantee fertilization success when the density of conspecifics is low or when environmental conditions contradict cross-fertilization (Brazeau et al. 1998). Moreover, gametes from the same colony are the closest in proximity when they reach the sea surface at spawning (Carlon 1999). This will favour self-fertilization unless there are active barriers preventing selfing such as gamete incompatibility (Palumbi 1994). A second explanation is that we lumped together P. meandrina and Pocillopora verrucosa, which are morphologically similar species. Difficulty in coral identification is a frequently encountered problem (Le Goff-Vitry et al. 2004b). For example, Pocillopora damicornis is known to exhibit a variety of confusing morphs depending on its habitat. Alternatively, a deficit of heterozygotes can result from the admixture of cohorts with different allele frequencies, resulting from temporally distinct recruitment events of larval cohorts (Lenfant \& Planes 2002). The deficit in heterozygotes can also result from a combination of several mechanisms (Gaffney et al. 1990 for a review of hypotheses).

The second explanation does not agree well with the facts. A mixing of species would probably produce local populations with different levels of admixture. However, 
four of the populations were genetically very similar and their deficit in heterozygotes was not lower than in the other populations. The two remaining explanations (inbreeding, and the admixture of successive larval cohorts) are more compatible with the generality of heterozygote deficits in our sampling.

\section{Absence of population structuring in the Society Islands}

Four populations, Mo2, Mo3, Ta and Bo, are very similar in two ways. First, they consistently show a lower genetic diversity than other populations. Second, they are not genetically different among themselves, but are significantly different from the other three populations, including Mo1 from Moorea (mean $F_{\mathrm{ST}}=0.024$ ). Paradoxical situations, where differentiation is higher at a local scale than a large scale, have previously been recorded in marine organisms. This was observed for corals at the Great Barrier Reef, where sites $2 \mathrm{~km}$ apart on the same reef were more differentiated than reefs several to hundreds of kilometres apart (Ayre \& Dufty 1994; Hellberg 1996; Ayre et al. 1997; Ayre \& Hughes 2000; Bastidas et al. 2001; Miller \& Ayre 2004). Such patterns may be the result of marine currents. The Society Islands are all subject to the same current that could promote larval dispersal between neighbouring populations along successive islands (Rougerie \& Wauthy 1986). This may explain the absence of population differentiation between islands. If so, why is Mo1 different from the other two populations from Moorea? Maybe because Mo1 is located on the west coast of Moorea and is more exposed to waves than Mo2 and Mo3 (both located on the north coast). If gene flow is mainly the result of physical factors, other species with a pelagic stage should show the same pattern. The damselfish, Dascyllus trimaculatus, shows significant structure between two sites from Moorea (corresponding to sites Mo1 and Mo2 in this study), whereas no structuring is observed across the Society Islands (Bernardi et al. 2001). Planes (1993) showed no differentiation among populations of the damselfish Dascyllus aruanus in this archipelago, whereas significant differentiation occurred for the surgeon fish Acanthurus triostegus (Planes 1993; Planes et al. 1996; Planes \& Fauvelot 2002), with no differentiation between populations from Moorea. Thus there is little support for a consistent effect of physical factors.

The second hypothesis is historical, and involves the destruction of the four currently similar Society Island populations followed by their restoration via the settlement of new larvae. These events would explain both their lower genetic diversity, and their genetic similarity. Reef destruction could be a result of many factors, such as an outbreak of the predator, Acanthaster planci (Faure 1989), or more probably to a bleaching event. Pocillopora corals experienced a quasi total mortality in the lagoon of the Rangiroa Atoll (French Polynesia, Tuamotu Archi- pelago) in 1998 (Mumby et al. 2001). Likewise, Pocillopora species underwent varying levels of mortality (from $60 \%$ to $90 \%$ ) in different stations of the northern outer slope of the reef in Moorea in 1994 (Hoegh-Guldberg \& Salvat 1995). An extended bleaching event in part of the Society Islands followed by recolonization would be similar to a population bottleneck, and could explain why the average heterozygosity for the genetic markers used in this study is high in the Tonga and in Mo1 (observed values: $0.804<$ $H<0.828$ ), and low in Bora Bora, Tahiti, and the two the remaining sampling sites in Moorea (observed values: $0.675<H<0.722$ ). The cause of this unexpected pattern merits further investigation. However, within the framework of this study, the very low genetic differentiation among islands of this archipelago provides evidence that extensive gene flow exists at this spatial scale.

In conclusion, our study confirms that the coral P. meandrina reproduces sexually in the south-central Pacific, and leads us to conclude that (i) genetic heterogeneity can exist at a local scale, and may result in significant differentiation between populations of the same reef (ii) the flow of migrants at the scale of the Society Islands is substantial and can genetically homogenize populations of different islands, and (iii) there is some limitation to long-distance migration, resulting in genetic heterogeneity at a broad geographical scale. In the context of our understanding of the key position of corals in the reef ecosystem, the ability to disperse and its spatial limitations are essential biological factors that will determine the resilience of Polynesian reefs after a bleaching event.

\section{Acknowledgements}

We thank Emmanuelle Baudry, Fenny Cox, Anne Génissel and Karen McCoy for helpful advice, valuable comments and corrections. We thank anonymous referees for their helpful comments. We thank the French Ministère de l'Outremer. This research was supported by a grant from the EPHE PPF network to Michel Veuille, by a grant from the TotalFinaElf Foundation to Mehdi Adjeroud, and by a Docteur-Ingénieur fellowship from the CNRS to Hélène Magalon.

\section{References}

Adjeroud M, Tsuchiya M (1999) Genetic variation and clonal structure in the scleractinian coral Pocillopora damicornis in the Ryukyu Archipelago, southern Japan. Marine Biology, 134 (4), 753-760.

Ayre DJ, Dufty S (1994) Evidence for restricted gene flow in the viviparous coral Seriatopora hystrix on Australia's Great Barrier Reef. Evolution, 48 (4), 1183-1201.

Ayre DJ, Hughes TP (2000) Genotypic diversity and gene flow in brooding and spawning corals along the Great Barrier Reef, Australia. Evolution, 54 (5), 1590-1605.

Ayre DJ, Hughes TP, Standish RJ (1997) Genetic differentiation, reproductive mode, and gene flow in the brooding coral Pocillopora 
damicornis along the Great Barrier Reef, Australia. Marine Ecology Progress Series, 159, 175-187.

Ayre DJ, Resing JM (1986) Sexual and asexual production of planulae in reef corals. Marine Biology, 90, 187-190.

Bastidas C, Benzie JAH, Uthicke S, Fabricius KE (2001) Genetic differentiation among populations of broadcast spawning soft coral, Sinularia flexibilis, on the Great Barrier Reef. Marine Biology, 138, 517-525.

Benzie JAH, Haskell A, Lehman H (1995) Variation in the genetic composition of coral (Pocillopora damicornis and Acropora palifera) population from different reef habitats. Marine Biology, 121, 731739 .

Bernardi G, Holbrook SJ, Schmitt RJ (2001) Gene flow at three spatial scales in a coral reef fish, the three-spot dascyllus, Dascyllus trimaculatus. Marine Biology, 138, 457-465.

Bierne N, Launey S, Naciri-Graven Y, Bonhomme F (1998) Early effect of inbreeding as revealed by microsatellite analyses on Ostrea edulis larvae. Genetics, 148, 1893-1906.

Brazeau DA, Gleason DF, Morgan ME (1998) Self-fertilization in brooding hermaphroditic Carribean corals: evidence from molecular markers. Journal of Experimental Marine Biology and Ecology, 231, 225-238.

Carlon DB (1999) The evolution of mating systems in tropical reef corals. Trends in Ecology and Evolution, 14, 491-495.

David P, Delay B, Berthou P, Jarne P (1995) Alternative models of allozyme-associated heterosis in the marine bivalve Spisula ovalis. Genetics, 139, 1719-1726.

Faure G (1989) Degradation of coral reefs at Moorea Island, French Polynesia by Acanthaster planci. Journal of Coastal Research, 5, 295-305.

Gaffney PM, Scott TM, Koehn RK, Diehl WJ (1990) Interrelationships heterozygosity, growth rate and heterozygote deficiencies in the coot clam, Mulina lateralis. Genetics, 124, 687-699.

Guo S, Thompson E (1992) Performing the exact test of HardyWeinberg proportion for multiple alleles. Biometrics, 48, 361372.

Hardy OJ, Vekemans X (2002) sPAGEDI: a versatile computer program to analyse spatial genetic structure at the individual or population levels. Molecular Ecology Notes, 2, 618-620.

Hellberg ME (1996) Dependence on gene flow on geographic distance in two solitary corals with different larval dispersal capabilities. Evolution, 50, 1167-1175.

Highsmith RC (1982) Reproduction by fragmentation in corals. Marine Ecology Progress Series, 7, 207-226.

Hoegh-Guldberg O, Salvat B (1995) Periodic mass-bleaching and elevated sea temperatures: bleaching of outer reef slope communities in Moorea, French Polynesia. Marine Ecology Progress Series, 121, 181-190.

Jokiel PL (1984) Long distance dispersal of reef corals by rafting. Coral Reefs, 3, 113-116.

Kramarsky-Winter E, Fine M, Loya Y (1997) Coral polyp expulsion. Nature, 387, 137.

Kumar S, Tamura K, Jakobsen IB, Nei M (2001) MEGA2: molecular evolutionary genetics analysis software. Bioinfomatics, 12, 12441245.

Le Goff MC, Rogers AD (2002) Characterization of 10 microsatellite loci for the deep-sea coral Lophelia pertusa (Linneaus 1758). Molecular Ecology Notes, 2, 164-166.

Le Goff-Vitry MC, Pybus OG, Rogers AD (2004a) Genetic structure of the deep-sea coral Lophelia pertusa in the northeast Atlantic revealed by microsatellites and internal transcribed spacer sequences. Molecular Ecology, 13, 537-549.
Le Goff-Vitry MC, Rogers AD, Baglow D (2004b) A deep-sea slant on the molecular phylogeny of the Scleractinia. Molecular Phylogenetics and Evolution, 30, 167-177.

Lenfant P, Planes S (2002) Temporal genetic changes between cohorts in a natural population of a marine fish, Diplodus sargus. Biology Journal of the Linnean Society, 76, 9-20.

Lopez JV, Kersanach R, Rehner SA, Knowlton N (1999) Molecular determination of species boundaries in corals: genetic analysis of the Montastraea annularis complex using amplified fragment length polymorphisms and a microsatellite marker. Biological Bulletin, 196, 80-93.

MacKenzie JB, Miunday L, Willis B, Miller DJ, Van Oppen MJ (2004) Unexpected patterns of genetic structuring among locations but no colour morphs in Acropora nasuta (Cnidaria; Scleractinia). Molecular Ecology, 13, 9-20.

Magalon H, Samadi S, Richard M, Adjeroud M, Veuille M (2004) Development of coral and zooxanthella-specific microsatellites in three species of Pocillopora (Cnidaria, Scleractinia) from French Polynesia. Molecular Ecology Notes, 4, 206-208.

Maier E, Tollrian R, Nürnberger B (2001) Development of speciesspecific markers in an organism with endosymbionts: microsatellites in the scleractinian coral Seriatopora hystrix. Molecular Ecology Notes, 1, 157-159.

Marquez LM, MacKenzie JB, Takabayashi M, Smith CR, Chen CA (2003) Difficulties in obtaining microsatellites from acroporid corals. Proceedings of the 9th International Coral Reef Symposium, 1, 139-143.

Miller DJ, Ayre DJ (2004) The role of sexual and asexual reproduction in structuring high latitude populations of the reef coral Pocillopora damicornis. Heredity, 92, 557-568.

Miller KJ, Howard CG (2004) Isolation of microsatellites from two species of scleractinian coral. Molecular Ecology Notes, 4, $11-13$.

Mumby PJ, Chisholm JRM, Edwards AJ, Andrefouet S, Jaubert J (2001) Cloudy weather may have saved Society Island reef corals during the 1998 ENSO event. Marine Ecology Progress Series, 222, 209-216.

Nei M (1978) Estimation of average heterozygosity and genetic distance for small number of individuals. Genetics, 89, 583590.

Nishikawa A, Katoh M, Sakai K (2003) Larval settlement rates and gene flow of broadcast-spawning (Acropora tenuis) and planulabrooding (Stylophora pistillata) corals. Marine Ecology Progress Series, 256, 87-97.

Nyström M, Folke C, Moberg F (2000) Coral reef disturbance and resilience in a human-dominated environment. Trends in Ecology and Evolution, 15, 413-417.

Palumbi SR (1992) Marine speciation on a small planet. Trends in Ecology and Evolution, 7, 114-118.

Palumbi SR (1994) Genetic divergence, reproductive isolation, and marine speciation. Annual Reviews of Ecology and Systematics, 25, $547-572$

Parsons KE (1996) The genetic effects of larval dispersal depend on spatial scale and habitat characteristics. Marine Biology, 126, $403-$ 414.

Pemberton JM, Slate J, Bancroft DR, Barrett JA (1995) Nonamplifying alleles at microsatellite loci: a caution for parentage and population studies. Molecular Ecology, 4, 249-252.

Piry S, Alapetite A, Cornuet J-M, Paetkau D, Baudouin L, Estoup A (2003) GENECLAss2: a software for genetic assignment and first generation migrants detection. Journal of Heredity, 95, 536539. 
Planes S (1993) Genetic differentiation in relation to restricted larval dispersal of the convict surgeonfish Acanthurus triostegus. French Polynesia. Marine Ecology Progress Series, 98, 237-246.

Planes S, Fauvelot C (2002) Isolation by distance and vicariance drive genetic structure of a coral. Evolution, 56, 378-399.

Planes S, Galzin R, Bonhomme F (1996) A genetic metapopulation model for reef fishes in oceanic islands: the case of the surgeonfish, Acanthurus triostegus. Journal of Evolutionary Biology, 9, 103-117.

Queller DC, Goodnight KF (1989) Estimating relatedness using genetic markers. Evolution, 43, 258-275.

Raymond M, Rousset F (1995) GENEPOP (version 1.2): a population genetics software for exact tests and ecuminicism. Journal of Heredity, 86, 248-249.

Rice WR (1989) Analyzing tables of statistical tests. Evolution, 43, 223-225.

Richmond RH (1993) Coral reefs: present problems and future concerns resulting from anthropogenic disturbance. American Zoologist, 33, 524-536.

Ridgway T, Hoegh-Guldberg O, Ayre DJ (2001) Panmixia in Pocillopora verrucosa from South Africa. Marine Biology, 139, 175181.

Rougerie F, Wauthy B (1986) L'Ocean qui Nous Entoure. Encyclopédie de la Polynésie, Vol. I: les îles océaniques, pp. 73-78. Multipress, Papeete, Polynésie Française.

Rousset F (1997) Genetic differentiation and estimation of gene flow from $F$-statistics under isolation by distance. Genetics, 145, 1219-1228.

Schneider S, Roessli D, Excoffier L (2000) ARLEQUIN, version 2.000: A Software for Population Genetics Data Analysis. Genetics and Biometry Laboratory. University of Geneva, Switzerland.

Severance EG, Szmant AM, Karl SA (2004) Microsatellite loci isolated from the Caribbean coral, Montastraea annularis. Molecular Ecology Notes, 4, 74-76.
Shlesinger Y, Goulet TL, Loya Y (1998) Reproductive patterns of scleractinian corals in the northern Red Sea. Marine Biology, 132, 691-701.

Slatkin M (1993) Isolation by distance in equilibrium and nonequilibrium populations. Evolution, 47, 264-279.

Sokal RR, Rolf FJ (1995) Biometry, 2nd edn. Freeman Co, New York.

Stoddart JA (1983) Asexual production of planulae in the coral Pocillopora damicornis. Marine Biology, 76, 279-284.

Stoddart JA (1984a) Genetic differentiation amongst populations of the coral Pocillopora damicornis off southwestern Australia. Coral Reefs, 3, 149-156.

Stoddart JA (1984b) Genetical structure within populations of the coral Pocillopora damicornis. Marine Biology, 81, 19-30.

Veron J (2000) Corals of the World. Australian Institute of Marine Science, Townsville.

Ward S (1992) Evidence for broadcast spawning as well as brooding in the scleractinian coral Pocillopora damicornis. Marine Biology, 112 (4), 641-646.

Weir B, Cockerham C (1984) Estimating F-statistics for the analysis of population structure. Evolution, 38, 1358-1370.

Whitaker K (2004) Non-random mating and population genetic subdivision of two broadcasting corals at Ningaloo Reef, Western Australia. Marine Biology, 144, 593-603.

Willis BL, Babcock RC, Harrison PL, Wallace CC (1997) Experimental hybridization and breeding incompatibilities within the mating systems of mass spawning reef corals. Coral Reefs, 16 (Suppl.), S53-S65.

This work is part of Helene Magalon's PhD. It is part of a joint project between Mehdi Adjeroud, a coral ecologist in Perpignan, and Michel Veuille, a population geneticist in Paris. 